Relations industrielles

Industrial Relations

\title{
Statistics on Labour Relations
}

Volume 4, numéro 5, janvier 1949

URI : https://id.erudit.org/iderudit/1023471ar

DOI : https://doi.org/10.7202/1023471ar

Aller au sommaire du numéro

Éditeur(s)

Département des relations industrielles de l’Université Laval

ISSN

0034-379X (imprimé)

1703-8138 (numérique)

Découvrir la revue

Citer cet article

(1949). Statistics on Labour Relations. Relations industrielles / Industrial

Relations, 4(5), 47-47. https://doi.org/10.7202/1023471ar

Tous droits réservés (C Département des relations industrielles de l’Université Laval, 1949
Ce document est protégé par la loi sur le droit d'auteur. L’utilisation des services d'Érudit (y compris la reproduction) est assujettie à sa politique d'utilisation que vous pouvez consulter en ligne.

https://apropos.erudit.org/fr/usagers/politique-dutilisation/ 


\section{STATISTICS ON LABOUR RELATIONS}

\section{Collective Agreements}

We have obtained from the Department of Labour the permission to publich interesting figures on the negotiation of collective agreements during the month of December, 1948.

Fifty-two collective agreements, covering 13,221 wage-earners, were lodged with the Labour Relations Board or at the Department of Labour in the course of the month. Here is the number of agreements credited to each organization :

The Canadian and Catholic Confederation of Labour : 20 agreements covering 9,336 workers;

The Canadian Congress of Labour : 12 agreements covering 531 workers;

The Trades and Labour Congress of Canada: 10 agreements covering 2,900 workers.

Deducting the abortive collective agreements, there are in force, at the present moment, under the Labour Relations Act 1,217 agreements covering 193,668 wage-earners. Of this number, 546 agreements covering 87,731 workers were negotiated by professional syndicates, and 671 agreements, covering 105,947 workers, were negotiated by non-incorporated unions.

\section{Arbitration Tribunals}

We find it of equal interest to do the same for the changes in arbitration tribunals during the month of December.

At the first of December, 1948 twenty tribunals were in existence. During the same month 6 new tribunals were organized and 10 rendered their judgments so that on the first of January, 1949 there were 16 tribunals in existence of which 6 were deliberating litigations affecting public services and 10 were studying litigations affecting private enterprises.
Here is the list of arbitration tribunals functioning December 31st, 1948 :

Hôpital St-Luc vs Alliance des Infirmières, Montreal; Hôpital Pasteur et Hôpital Notre-Dame, Montréal; Municipal Employees, Shawinigan Falls; Lou Heft Inc.; Shawinigan Foundries; J.-L. Vachon \& Fils; Fonctionnaires municipaux (Section des Infirmières), Montréal; M.-E. Binz, Montmagny; Somerset Knitting; Services hospitaliers, Québec; Taggart Service Ltd.; Cable, Conduits and Fittings Ltd.; Canadian Tube and Steel Products Ltd.; J. W. Duncan; Institutrices de Lauzon; Canadian Marconi Limited.

\section{Professional Syndicates}

About 900 Professional Syndicates are presently incorporated under the Professional Syndicates Act. Some are groupings of wage-earners, others are groupings of employers nad even of farmers. The Provincial Secretariat has given us a report on the activities in the field of incorporation in the course of the year just finished.

In 1948, 162 syndicates were incorporated. Of this number 110 are groupings of wage-earners, $\mathbf{9}$ are groups of employers and there are $\mathbf{4 3}$ Circles of the Union of Catholic Farmers :(Union Catholique des Cultivateurs).

In the last two or three years many affiliations of the Union of Catholic Farmers have judged it wise to take advantage of the Professional Syndicates Act. These Circles have found here not only the possibility of a legal existence but also quite considerab!e advantage from the mutual and co-operative point of view. 